\title{
Conceptual Model of Strategic Management of the Value of Technological Cluster
}

\author{
V.V.Velikorossov ${ }^{1, *}$, Y.M.Bryukhanov ${ }^{1}$, M.I.Maksimov ${ }^{1}$, S.A.Filin ${ }^{1}$, V.A.Kozlov ${ }^{1}$, \\ A.K.Khudaibergenov ${ }^{2}$ \\ ${ }^{1}$ Department of Organizational and Administrative Innovations, Plekhanov Russian University of \\ Economics, Moscow, Russia \\ ${ }^{2}$ L.L.C. «Husnutdin Saliev», Nukus, Uzbekistan \\ *Corresponding author
}

Keywords: Integrated Consumer System, Motivational Mechanism, Introduction of Innovations to the Market, Value of the Technological Cluster.

Abstract: The main disadvantage of the existing national organizational and economic mechanism for bringing innovations to the market is the discrepancy between investors' motives and fast turnover of the nomenclature, shortening the life cycle of goods and services. From the standpoint of the manufacturer, it takes time to form a critical mass that covers the expenses of innovations. The longer the innovation life cycle, the greater the income the manufacturer receives and the higher the return on investment. The stage of transition from the seed stage to scaling is insufficiently funded. To change the situation, we need forms of investors' motivation based on the interests of integrated consumers in conditions of pyramidal integration.

\section{Introduction}

The strategic management of the technological cluster at the meso level using the value approach has not yet received a complete description in the studies of foreign and Russian scientists. J.P. Stegmann [1] proposed a methodological approach to the strategic management of the value of the company, he identified the key factors in creating the value of the company: resources, monopoly power and innovation, which form the basic elements of the mechanism of strategic management of the value of the company: capital (resource), sustainable growth (process), profit (goal). The modern digital environment of business offers new methods of influencing the factors of the mechanism of strategic management - blockchain technology and the institution of equal level trust, as well as the pyramid motivation for investors to receive speculative income [2,3]. Let's consider the development of the technological cluster of microelectronics.

The global microelectronics market is estimated at 400 billion US dollars of annual production, where Russia's share of manufactured microelectronic components is about $1 \%$, while a significant part of the hardware components purchased from abroad. The revenue per worker at Russian hightech enterprises in microelectronics, lags behind the market leaders in 10-15 times [4]. The lack of monopoly power in the microelectronics market reduces profit opportunities attractive to investors. Therefore, pyramidal motivation mechanisms can be effective, allowing investors to earn 
speculative income by financing the growth of computing power, an example of which can be an integrated pyramid in a distributed network of crypto obligations [5].

\section{Statement of the Problem Research}

The interests of state investors - Development Centers of the Russian Federation are resources for creating a technological cluster. The behavior motive of Development Centers lies in the return on investment, which implies large-scale production, achieving economies of scale, but in the absence of monopoly power, the likelihood of successful implementation of this motive is reduced. This motive also impedes the implementation of a differentiation strategy, and standardization leads to commoditization of new products, simplification, lower costs to accelerate payback and creates growth barriers.

Private investors, business - angels are focused on the model of creating promising innovations from the point of view of manufacturers. But the manufacturer is not always able to correctly determine the future needs and values of innovation for consumers. The business angels' activity is associated with the risk of losing the invested funds, and they are most interested in providing the conditions for achieving a critical mass of innovations, and not in the rapid turnover of one innovative project to others, since quick turnover will lead to a loss (shortfall) of return on investment. This property characterizes the inefficiency of the mechanism for bringing innovations to the market.

Venture investors are not focused on customers, on creating value not for themselves, but for consumers. If the project is successful, the initial investment quickly pays off, however, to achieve this in the absence of monopoly power is almost impossible, since significant financial resources are required for the further promotion of the product to the market.

Venture funds are different from the union of private investors (business angels) in that they manage not only their own, but also other people's money. And venture funds do not invest in projects that are at the seed stage. Their goal is to scale innovation, increase the duration of the life cycle of innovation, which is not consistent with the trend to accelerate the update of product lines.

Thus, the financing of the immanent stage of the innovation process, i.e. testing, drops, the resource gap in the value chain hinders technological growth. In the absence of monopoly power, financing innovative development of a technology cluster will be efficient and sufficient in the case when it is implemented by integrated consumers testing increasing computing power and motivated by a pyramid scheme, as in the case of distributed networks of cryptoactive assets.

According to economic theory, the successful introduction of scientific and technical elaboration is accompanied by its scaling, increase in the volume of supply, which changes the price of such a proposal. In the context of reducing the life cycle of products, the importance of market testing and the rate of change in the supply of products increases, that is the modern paradigm of sustainable growth of the value of the technology cluster. The integrated consumer system based on the pyramid creates a feverish demand for products, creating an advance payment for a future product, for example, by financing testing of the microelectronic element base of computing power. New micro electronic elements are tested by integrated users and conditions are being created for eliminating defects in the distributed network system, since each node has equal rights. The existence of conditions for the gain of speculative income by producers of microelectronic components acting as anonymous participants of the pyramid scheme should be also recognized.

The manufacturer, which brings to the market the best innovation - an integrated microcircuit (ASIC), is more competitive and in demand among integrated consumers who are willing to invest in innovation in order to gain consumer value. Integrated consumers are ready to pay the rush price 
for power in order to get a return on investment within 7 months, including through the rush, as happens in a distributed Bitcoin network.

None of the definitions of digital assets reveals the Bitcoin network as a mechanism for strategic management of the value of a technology cluster, but thanks to this mechanism the element base for computing power has developed from $20 \mathrm{H} / \mathrm{s}$ to $13.5 \mathrm{TH} / \mathrm{s}$ in a short time, i.e.1 billion times, which shows the high efficiency of the system of integrated consumers, using a pyramidal structure to create speculative income in the strategic management of the value of the technological cluster.

The economics of the Bitcoin network showed that the effectiveness of the new distributed pyramidal mechanism for financing the sustainable development of the technology cluster is much higher than the current one. One of the main advantages of the Bitcoin network is that it is protected from inflation and, as practice shows, against bankruptcy, since the issue procedure is programmed to complicate income generation and to protect the pyramid from early termination of obligations. The increasing complexity of income generation motivates financing the creation of the new computing power.

The main advantages of this mechanism are: the absence of a development center; the vertical structure of the technological cluster's value management is transformed into a flat one; , technology cluster initiates the operation of a distributed network and maintains its liquidity, in which the algorithm is an emission center, maintain control and release restrictions with providing of the "complete anonymity"; the ability to generate digital assets independently through mining; protection from early termination of obligations; the absence of environmental factors (excluding for market supply and demand).

The pyramid is a motivational mechanism for increasing participants' income. Not all pyramidal digital asset systems are equally motivated to create computing power. The rush motivation requires monopoly power. We will make a rating of monopoly power, which we will express through the capitalization of crypto obligations (Fig. 1) [6, 7]. The total capitalization of crypto assets exceeds the budget of the National Program "Digital Economy of Russia" (NP DER) [8].

The pyramidal mechanism of motivation follows the life cycle of technological cluster innovations. Bitcoin exchange rate decline is caused by the limit of development of computing power based on existing technical principles, as soon as the technical barrier of computing power is overcome, then the rate of Bitcoin will begin to grow again, causing the rapid commercialization of a new micro electronic element base. The quotes jump coincides with jumps in the development of technical capabilities.

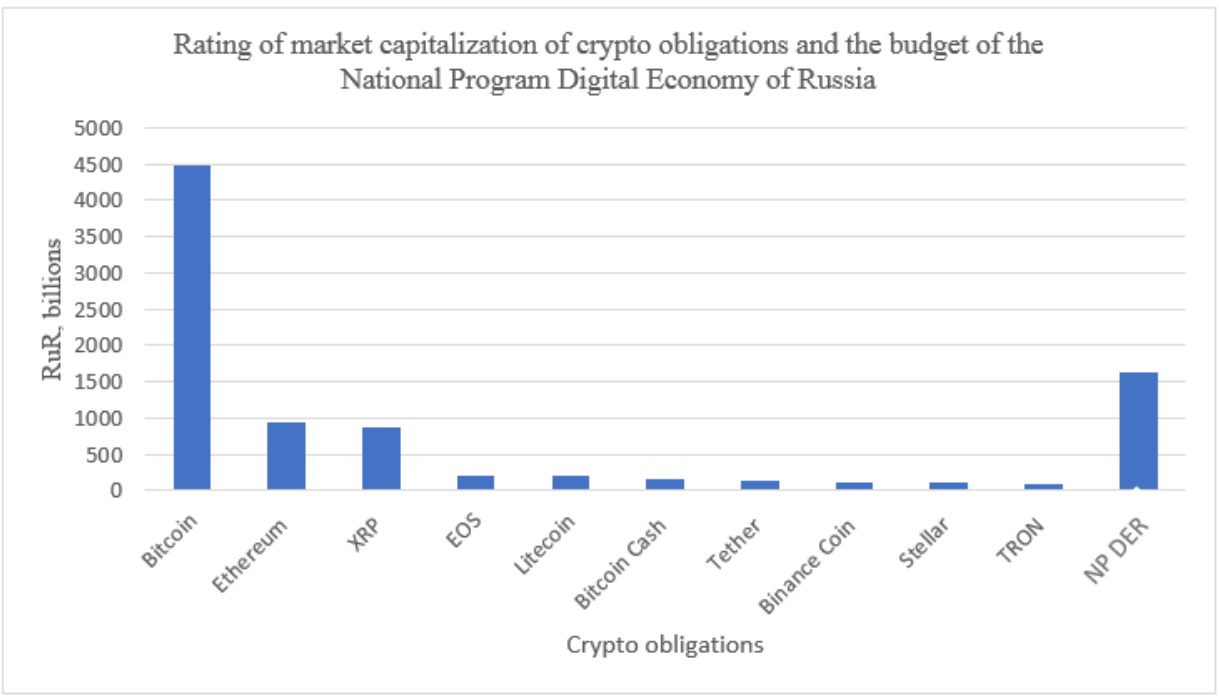

Figure 1. Rating of the Monopoly Power of Digital Assets on February 2019 
Investors of the pyramid of Bitcoin to obtain speculative income have gone through several evolutionary stages of creating a technological cluster based on the innovative development of computing power, which contributes to the economic growth of the technological cluster. The target investment complex includes:

1. Minerd. Motivates the improvement of processors.

2. Cgminer. Motivates the production of video cards ATI.

3. Cudaminer. Motivates the production of video cards Nvidia.

4. Antminer. Motivates the production of integrated circuits ASIC-chips.

The collective investment form of the technology cluster is implemented in the form of computing farms. Individual investors unite in integrated communities to increase opportunities for speculative income and thus develop a speculative mechanism. When a block is created in a bitcoin distributed network, the computational powers of thousands of other miners, who are also motivated to participate in the innovation value creation process of the technology cluster, are involved in the pool.

The analysis reveals the correspondence of the increase in the capitalization of digital assets with the booste in computing power as a result of the implementation of innovative processes. For effective work of the organizational and economic mechanism, it is necessary to maintain the liquidity of crypto assets, which is carried out through a network of trading platforms.

There are significant differences between the pyramidal motivational mechanism and the financial (investment) pyramid: if the main income method of the first participants of the financial pyramid is guaranteed through the involvement of new participants' funds, the motive for creating crypto obligations is formed as a result of free sale on the exchange and solving the counting problem in an increasingly complex algorithm based on improved computing power. The participants of distributed networks, who entered the network and began to generate crypto obligations first, receive greater value, because in the future it is becoming more and more difficult to create new blocks of a distributed network. In most cases, subsequent participants only have to buy crypto obligations for the fiat currency directed to the development of microelectronics.

\section{Description of the Research Problem Solving Method}

For the description and solution of the tasks used, models of optimal management of financial pyramids were used within the framework of the deterministic approach proposed by S. Dubovskiy. and developed by G.G. Dimitriadi, employees of the Institute of System Analysis of the Russian Academy of Sciences, currently ISA IM RAS [9].

Brief presentation of the motivational pyramid model on the example of a distributed network of crypto obligations. A person (group of initiators) organizing the implementation of the Bitcoin network algorithm issues its 21 million BTC, for which he (they) must pay a certain amount later (\$ 100 billion), and these obligations are fulfilled only with the use of profit from creating new blocks. Suppose that the organizer fulfills all obligations until a certain point, called the completion of the pyramid.

Obligations of the organizing person without imposing restrictions on power will be calculated as BTC, and the total number of obligations for all BTC will be called the motivational potential. Without introducing a power limit, we assume that the motivational potential equals the BTC exchange rate.

We use the following notation. Let us assume that the motivational mechanism, the motivational pyramid, has a starting instant of time $t=0$ (2009).

$\mathrm{G}(\theta)$ - the volume of BTC (21000 -17097), which was outstanding by the time t, BTC of those present in the circulation of the pyramid at face value; 
$\mathrm{V}(\mathrm{t})$ - computing power costs;

$\mathrm{W}(\mathrm{t})$ - the total income of those who invested in the motivational pyramid (\$104,618,455,275 USD), which is about $2.5 \%$ of the sales of microelectronics;

$\mathrm{G}(\mathrm{t})$ - the volume of BTC sold by the organizer at time $\mathrm{t}$ at face value;

$\theta>0$ - the deadline, at the end of which the moment of fulfillment of the obligations of the organizing person comes, measured from the time of the start of the sale of obligations (2022-2029);

$\mathrm{G}(\mathrm{t}-\theta)$ - the volume of the BTC sold by the organizer by the instant of time $t-\theta$ at the face value, which must be repaid at the instant of time $t$.

g (c) $t \in[[0 ; 6,118.97$ USD] - price provided as a fraction of the nominal value at which BTC sales are made at instant of time $t$.

Suppose that a bitcoin with a general defined maturity $\theta$ relative to the time of their implementation is bought. The technology cluster fulfills obligations to invested persons using the income from the sale of BTC within the pyramid, with the involvement of funds from the sale of microelectronics.

Within the framework of the financial pyramid, the Organizer fulfills its obligations to the participants only at the expense of the proceeds from the sale of bitcoins, that is, without attracting funds from outside. Based on the economic meaning of the entered values and the assumptions made, it is possible to record the rate of increase in the volume of crypto obligations, the function of motivated demand, the rate of increase in computing power, the rate of increase in income of participants in a distributed network (motivational potential), the payback period of special integrated circuits.

However, crypto obligations do not have the property of targeted obligations. They have no guarantee of the issuer, and their importance is based only on managed expectations of investors.

In relation to them, there is no difficulty in limiting liquidity, while even in the case of the expenditure of the entire number of crypto obligations, since the crypto obligation is divided into smaller shares. The target size of the crypto obligation is known in advance, and the formation of any new block in the Bitcoin network is accompanied by a complication of the search algorithm, which leads to a synthetic limitation of the rate of increase in supply.

\section{Applied Interpretation and Illustration of the Research Results}

The issue of crypto obligations is decentralized (Fig. 2).

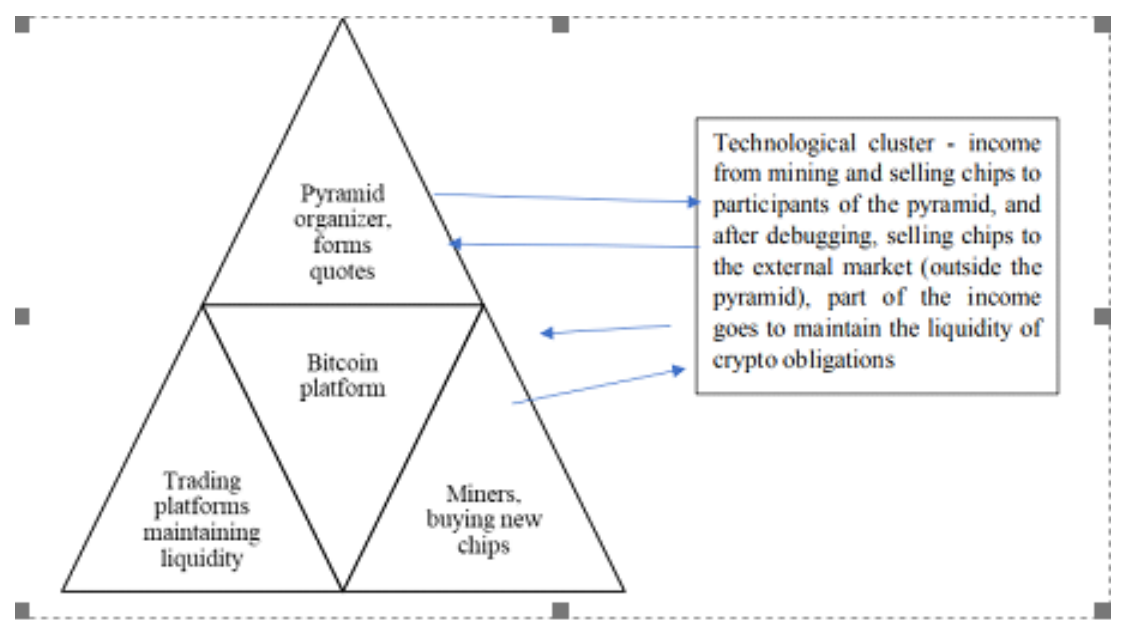

Figure 2. Introducing Integrated Circuits Based on a Pyramidal Integrated Distributed Network onto the Market 
The increase in the volume and use of crypto obligations in transactions is guaranteed by miners who create new constructions for records in order to extract emission earnings. The formation of new designs is accompanied by additional emission. Miner receives a part of the created crypto obligations in the form of remuneration. Information about transactions is in the public domain, only individual information of participants is hidden. Transactions are considered irrevocable and executed P2P (peer to peer at the same level).

Currently, the emission center of crypto obligations is an algorithm - a bot with the beginnings of artificial intelligence. With the addition of a distributed network participant, the difficulty of creating additional value increases, the predicted value of creating a quantum computer. The motivational mechanism will fulfill its task.

\section{Conclusion}

Flat distributed procedure of innovation launching to the market, based on the principle of motivation to create added value to the integrated consumers and delivers economic growth of the technology cluster. Resources of integrated circuits consumers form the capital, and monopoly power in the market of crypto assets can generate profit from the sale of computing power. In practice, for distributed networks of digital assets are innovations in microelectronics stands, increasing the speed and amount of memory, improving software, revealing the direction of the applied use of the blockchain, all this happens against the background of competition in this ecosystem.

Digital pyramid technologies of innovative products launch on the market can be used and are already used to promote grocery, technological, organizational and managerial innovations. From virtual reality they move into augmented reality. Thus, augmented reality, embodied in flat integrated structures, allows to increase the value of technological cluster.

\section{References}

[1] Stegmann J.P. Strategic value management: stock value creation and the management of the firm. John Wiley \& Sons, Inc., Hoboken, New Jersey.2009, 298 p.

[2] Bryuhanov YU.M., Velikorossov V.V. Metodologicheskij podhod k strategii formirovaniya cifrovoj ekonomiki / Organizacionno-upravlencheskie i sociokul'turnye innovacii v razvitii cifrovoj ekonomiki i sistem elektronnogo obrazovaniya. T.2: sbornik statej / pod red. V.V.Velikorossova, A.V. Kolesnikova.- M.: RUSAJNS, 2019.- S.13-19

[3] Khachaturyan M.V., Klicheva E.V., Velikorossov V. V. (2019) Digital Mechanisms of Development of Possessory Risk Management Systems under New Economic Conditions. Proceedings of the 2019 International Conference on Politics, Economics and Management (ICPEM 2019). Lecture Notes in Economics, Management, and Social Sciences. Clausius Scientific Press, Vol. 5. P. 6-10.

[4] Bodnar' D., Poluprovodnikovaya mikroelektronika - 2017 g. CHast' 1. Rynok mirovoj mikroelektroniki http://www.syntezmicro.ru/uploads/files/pub/Article28-1.pdf (data obrashcheniya: 12.09.2018).

[5] Velikorossov V.V., Bryuhanov YU.M, Donskaya S.L. Konceptual'naya model' strategicheskogo upravleniya innovacionnymi processami na osnove ploskoj raspredelitel'noj ekosistemy (na primere razvitiya integrirovannyh piramid $\mathrm{v}$ raspredelennyh setyah kripto obyazatel'stv) // Ekonomika i upravlenie: problemy, resheniya, 2019. T.2 (87).- № 3.- S. 126-133. 
[6] Svedeniya o rynochnoj kapitalizacii kriptovalyut, ih ob"emah torgov i tekushchej cene v osnovnyh valyutah https://coinmarketcap.com/ru (data obrashcheniya: 12.09.2018).

[7] Filin S.A. Strategicheskie tekhnologicheskie platformy kak osnova tekhnologicheskoj bezopasnosti Rossii v budushchem Nacional'nye interesy: prioritety i bezopasnost'. 2019. T. 15. № 1 (370). S. 18-34.

[8] Pasport nacional'noj programmy «Cifrovaya ekonomika Rossijskoj Federacii» URL: http://static.government.ru/media/files/urKHm0gTPPnzJlaKw3M5cNLo6gczMkPF.pdf (data obrashcheniya: 12.09.2018).

[9] Dimitriadi G.G. Modeli finansovyh piramid: determinirovannyj podhod / Ros. akad. nauk. In-t sistem. analiza. - M.: URSS, 2002 (Rohos). - 33 s http://www.mirkin.ru/_docs/book015.pdf (data obrashcheniya: 12.09.2018). 